\title{
NATURAL OCCURRENCE OF S-ALKYL GLYCEROL ETHERS IN EHRLICH ASCITES CELLS
}

\author{
William J. Ferrell and Antonio Garces* \\ Departments of Pathology and Biological Chemistry. The University of Michigan. \\ Ann Arbor, MI 48109 U.S.A.
}

(Received 11 May 1977)

\begin{abstract}
S-alkyl glycerol ethers were isolated by thin-layer chromatography from the total lipids of Ehrlich ascites cells following reduction with vitride.

2. Gas-liquid chromatography of the isopropylidene derivatives showed the principal component to be $16: 0(83 \%)$ with lesser amounts of $18: 1(14 \%)$ and $18: 0(2 \%)$

3. Quantitative analysis yielded values of about $2 \mu$ moles $/ 100 \mathrm{mg}$ lipid for the isolated thioethers.
\end{abstract}

\section{INTRODUCTION}

Bovine and human heart have been shown to contain $S$-alkyl glycerol ethers (glycerol thioethers) as components of the non-polar lipids, resembling the $O$-alkyl glycerol ethers in composition (Ferrell \& Radloff, 1970 ; Ferrell, 1973). The hinsynthesis of $S$-alkyl glycerol ethers by liver microsomes has been found to occur by a pathway analogous to the biosynthesis of $O$-alkyl glycerol ethers (Ferrell \& Desmyter, 1974). The occurrence and biosynthesis of $O$-alkyl glycerol ethers in Ehrlich ascites cells is well established (Wood, 1973; Hajra, 1973). This paper describes the isolation of $S$-alkyl glycerol ethers from Ehrlich ascites cells.

\section{EXPERIMENTAL PROCEDURES}

\section{Materials}

All solvents and chemicals used were of the highest possible purity. Silica gel $G$ and GLC column packing were purchased from Applied Science Laboratories. Vitride was purchased from Eastman Kodak Co.

$S$-alkyl glycerol ethers of varying chain lengths were synthesized as we described earlier (Ferrell et al., 1976).

\section{Methods}

The Ehrlich ascites tumor cells (a hypotetraploid strain) were grown in the abdominal cavities of 54 Swiss mice and were harvested 7 days after inoculation. A total of $250 \mathrm{ml}$ of fluid was collected and the cells obtained by centrifugation at $2000 \mathrm{~g}$ for $2 \mathrm{~min}$.

The lipids were extracted from the cells using the Bligh and Dyer method (Bligh \& Dyer, 1959). A total of $1.63 \mathrm{~g}$ of lipid was obtained. This total lipid was reduced (in several aliquots) with vitride essentially as described by others (Wood \& Snyder, 1968). The main difference in the procedure was substituting chloroform-methanol $(4: 1 \mathrm{v} / \mathrm{v})$ for diethyl ether as the extracting solvent. We reported earlier that diethyl ether does not adequately extract the $S$-alkyl glycerol ethers (Ferrell \& Desmyter, 1974). The various extractions were combined and evaporated to dryness using a rotary evaporator. The residue was dissolved in chloroform and subjected to TLC with hexane:diethyl

* Present address: University of Carabobo, Valencia, Carabobo. Venezuela. ether:acetic acid $(30: 70: 1 \mathrm{v} / \mathrm{v} / \mathrm{v})$ as the developing solvent. The lipids were visualized under u.v. light after spraying with $0.005 \%$ thodamine $6-\mathrm{G}$ in $78 \%$ aq. methanol. This solvent separates the $O$-alkyl and $S$-alkyl glycerol ethers (Ferrell, 1973), however the $O$-alk-1-enyl (plasmalogens) and $S$-alkyl glycerol ethers chromatograph together. Therefore, the $S$-alkyl glycerol ether band was scraped from the plate, eluted with chloroform and the solvent evaporate under $\mathrm{N}_{2}$. The residue was then exposed to $\mathrm{HCl}$ gas for $35 \mathrm{~min}$, a procedure we have shown to destroy any O-alk-1-enyl glycerol ethers (Ferrell et al., 1970). The products were then separated by TLC using diethyl ether: $30 \%$ aq. $\mathrm{NH}_{4} \mathrm{OH}(100 ; 0.25 \mathrm{v} / \mathrm{v})$. We have shown this developing solvent to also work well for the separation of $S$ - and $O$-alkyl glycerol ethers yielding respective $R_{F}$ values of 0.29 and 0.16 (Ferrell et al., 1976). The $S$-alkyl glycerol ether band was scraped, eluted and evaporated to dryness under $\mathrm{N}_{2}$. The isopropylidene derivatives were synthesized and purified by TLC as described earlier (Ferrell et al., 1976). These isopropylidene derivatives were qualitatively analyzed by GLC as described previously (Ferrell, 1973). Peak areas were determined as the product of peak height and width at half peak height. Percentages were calculated in terms of peak areas. Peak identification was made by co-chromatography with synthetic standards.

Quantitative analyses were made as hydrazones (Ferrell et al., 1969) following periodate oxidation (Gelman \& Gilbertson, 1969) of the $S$-alkyl glycerol ethers.

\section{RESULTS AND DISCUSSION}

Following the exposure to $\mathrm{HCl}$ gas a hydrazone analysis for $O$-alk-1-enyl glycerol ethers was negative. NMR and IR spectra of the isolated $S$-alkyl glycerol ether band was identical to that obtained with purified synthetic standards (Wood et al, 1970; Ferrell et al., 1976).

The results of three separate isolations using $500 \mathrm{mg}$ samples of total lipids from the Ehrlich ascites cell are given in Table 1. The principal component is the 16:0 compound with significant amounts of $18: 1$ also being present as well as small amounts of $18: 0$.

The quantitative analysis of the $S$-alkyl glycerol ethers from the three $500 \mathrm{mg}$ aliquots give values ranging from $2.16 \mu$ mole/ $100 \mathrm{mg}$ lipid to 2.7 $\mu$ mole $/ 100 \mathrm{mg}$ lipid. This represents approx $0.8-1 \%$ 
Table 1. Distribution of $S$-alkyl glycerol ethers in Ehrlich ascites cells

\begin{tabular}{crrr}
\hline Shorthand & \multicolumn{3}{c}{ Experiment } \\
designation & A & \multicolumn{1}{c}{ B } & \multicolumn{1}{c}{ C } \\
\hline $16: 0$ & 83.6 & 82.9 & 83.8 \\
$18: 0$ & 2.4 & 2.8 & 2.1 \\
$18: 1$ & 14.0 & 14.3 & 14.1 \\
\hline
\end{tabular}

of the total lipid. In contrast, the sum of the $O$-alkyl and $O$-alk-1-enyl glycerol ethers in Ehrlich ascites cells is of the magnitude of $2.3 \%$ of the total lipids (Howard et al., 1973). In human heart, the approximate value for $S$-alkyl glycerol ethers was $0.09 \mu \mathrm{mole} / 100 \mathrm{mg}$ lipid (Ferrell, 1973).

Acknowledgement-This investigation was supported in part by research grant HL-16200 from the National Heart and Lung Institute.

\section{REFERENCES}

Bligh E. G. \& Dyer W. J. (1959) A rapid method of total lipid extraction and purification. Can. J. Biochem. 37, $911-917$.

FERRELL W. J. (1973) Glycerol thioethers in human heart. Lipids 8, 234-235.

FerRell W. J. \& RadlofF D. M. (1970) Glycerol thioethers: a new naturally occurring lipid from bovine heart muscle. Physiol. chem. Phys. 2. 551-558.
Ferrell W. J. \& Desmyter E. A. (1974) Studies on the biosynthesis of $S$-alkyl bonds of glycerolipids. Physiol. chem. Phys. 6. 497-503.

Ferrell W. J., Radloff J. F. \& JACKIW A. B. (1969) Quantitative analysis of free and bound fatty aldehydes: optimum conditions for $p$-nitrophenylhydrazone formation. Lipids 4, 278-282.

FerRell W. J., Radloff D. M. \& RadlofF J. F. (1970) Method for hydrolysis and isolation of plasmalogenbound fatty aldehydes. Analyt. Biochem. 37, 227-235.

Ferrell W. J., Garces A. \& Desmyter E. A. (1976) Synthesis and properties of ${ }^{35} \mathrm{~S},{ }^{14} \mathrm{C}$ and ${ }^{3} \mathrm{H}$-labeled $S$-alkyl glycerol ethers and derivatives. Chem. phys. Lipids 16, 276-284.

Gelman R. A. \& Gilbertson J. R. (1969) The quantitative and qualitative analysis of alkyl $x$-glycerol ethers as alkoxy acetaldehydes. Analyt. Biochem. 31, 463-470.

HAJRA A. (1973) The role of acyl dihydroxyacetone phosphate in tumor lipid metabolism. In Tumor Lipids: Biochemistry and Metabolism (Edited by WoOD R.) p. 183. American Oil Chemical Society Press, Champaign, IL. Howard B. V., Butler J. D. \& Bailey J. M. (1973) Lipid metabolism in normal and tumor cells in culture. In Tumor Lipids: Biochemistry and Metabolism (Edited by WooD R.) p. 200. American Oil Chemical Society Press, Champaign, IL.

WOOD R. (1973) Tumor lipids: structural and metabolism studies of Ehrlich ascites cells. In Tumor Lipids: Biochemistry and Metabolism (Edited by Wood R.) p. 139. American Oil Chemical Socicty Prcss. Champaign, IL. WOOD R. \& SNYDER F. (1968) Quantitative determination of alk-1-enyl and alkyl glycerol ethers in neutral and phospholipids. Lipids 3, 129-135. 